\title{
Poly Comb Group Proteins A Dual Player in Ageing and Cancer
}

\author{
M Krishnaveni* \\ Department of Biochemistry, Periyar University, India \\ Submission: August 27, 2017; Published: October 20, 2017 \\ *Corresponding author: M Krishnaveni, Assistant Professor, Department of Biochemistry, Periyar University, Salem-636 011, India, \\ Email: krishnavenim2011@gmail.com
}

\section{Introduction}

Maintenance of health at middle age is more important to have a longer disease free life. Every human stem cells are exposed continuously to several genotoxic stimuli from younger age, which are repaired by DNA repair process using DNA polymerase $\delta 1$, at some point during ageing, the ability to repair the damage was exhausted followed by instability in genome, causing cancer in elderly. This confirms the association of longevity to repair process. Ageing is a common factor, which occurs due to the damage in the macromolecule, organelle, cells, tissues and it is not a disease. Ageing is a key risk factor in the development of cancer among $60 \%$ of the people. Most of the mutations leading to cancer are linked with ageing. Ageing process weakens mitochondrial functions, creating more ROS and cause mutations in DNA of nuclear and mitochondria, improper DNA repair process, loss of replication leading to defective or oxidized protein synthesis and cancer. Altered functional enzymes linked with the activation of carcinogens make aged tissues more accessible to the effect of carcinogens that reside in the cell for a long time. The ageing and cancer are linked through the effect of endogenous stress (ROS) on DNA. The telomere shortening that takes place with each cell division makes the cell to enter in to a senescence stage, thereby cell cycle arrest, a normal process that is essential for tumor suppression. There are also reports of shorter telomere and telomere malfunction as well as more senescence cells accumulation formed by irreversible arrest of cell growth during ageing offers conducive tissue environment that enhances tumor promotion. Usual telomere loss is balanced by telomerase, which adds telomeric repeats per cell division but stem cells lack telomerase to do its function and hence more chromosomal damage via telomere. Short telomeres increase the risk of breast cancer [1]. Senesence cells also fuel pre malignant keratinocytes, epithelial cells (mammary gland) to malignant. Thus senescence is playing a dual role. In young age, it is a normal mechanism helps to survive against cancer but in older age, the same is tumorigenic. Genetic modification like point mutation, DNA hypermethylation and chromosomal translocation prepares ageing tissues toward tumor [2-6].

\section{Poly Comb Group Pproteins}

DNA methylation takes place through an enzyme DNA methyl transferase in order to add methyl groups to cytosine residues which are placed next to guanine. In human being, almost $90 \%$ of CpG sites are methylated and the balance $10 \%$ is nonmethylated $\mathrm{CpG}$ sites are grouped as island, situated in the promoter region towards 5' end. Changed methylation occurs in cancer cells DNA through hypo and hypermethylation at promoter region of $\mathrm{CpG}$ Island. Increased cytosine methylation of tumor suppressor gene causes natural deamination and thymine synthesis, followed by point mutation and uncontrolled cell proliferation. Many tumor suppressor genes contain $\mathrm{CpG}$ repeats as islands in their promoter region, which is normally unmethylated but its methylation lead to downstream gene transcription failure, enhancing gene silencing. These epigenetic changes in hematopoietic stem cells are regulated by polycomb group proteins that determine the functions of normal and cancer stem cells. The fate of the cell before birth until death was decided by cell fate transcription factors (Hox, Sox, Pax, Fox, Gata etc.). More than thirty abnormal/altered transcription factors are required for tissue specific cancer growth. So, they form a main regulatory role in attaching and detaching poly comb group proteins to specific target gene [7]. These proteins bind to their respective domain in the promoter region of genes for effective repression to takes place or silencing. In order to maintain its suppressor function at the time of cell division, poly comb group proteins binds to chromatin, DNA throughout the process of DNA replication, such binding have an effect on availability of DNA strand for transcription and its subsequent altered translation. Because DNA packaging in to the chromatin structure is a key factor for gene accessibility for its transcription and regulation. Poly comb group proteins are first discovered in Drosophila, regulating the Hox gene expression starting from flies to human beings $[8,9]$. These polycomb proteins are 
essential for the maintenance of identity in a cell by chromatin preservation $[10,11]$. As well as to maintain a balance between hematopoietic stem cell aging and cancer growth because any interruption in poly comb group proteins will affect cellular process like fate, senescence, DNA repair and apoptosis. In hematopoietic cancer this protein was misregulated. Mutant embryos of mammals lacking polycomb group proteins are committed to death during implantation stage [12-14]. Nearly $3-4 \%$ of genes regulated by polycomb group protein are transcription factors and target genes in embryonic stem cells are prone to be hypermethylated 12 times in aged somatic cells [15]. According to studies, 50\% genes are hypermethylated in colon, prostate cancers are premarked by poly comb proteins. Poly comb protein BMI 1 (Poly combring finger protein 4 or 51) is a subunit of polycomb repressive complex1 (PRC1) encoded by gene BMI 1, control the differentiation of stem cells. PRC 1 includes Bmi-1, Me118, cb, mph, ring. BMI1 regulate senescence and proliferation by regulating cell cycle inhibitor genes such as p16 and p19, essential to hold the self renewing capacity of stem cells, in case of any modification in the cell cycle inhibitor genes, it permit BMI1 to transform normal stem cells into cancerous (oncogenic) and also it inhibits neuronal ageing via p53 suppression [16]. BMI 1 was altered in few cancers like squamous cell bladder, leukemia, brain and thus marker for cancer [17-20]. Its loss leads to defective DNA repair system. Various processes such as oncogene activation, DNA damage, telomere shortening stimulate the onset of cellular senescence are delayed by BIM1, CBX7, CBX8 (polycombgroup proteins) in fibroblast embryo of mouse and human [21] by reducing p16 and p14 levels. All senescence cells are active metabolically and alive but the ability to divide is lost so as to prevent the growth of damaged cells. Proliferation of cancer, normal cells is altered via an interaction between polycomb group proteins and cyclin dependent kinases. CDKN2A and 2B encoding three cellular senescence inducers (p14, p15, p 16) were repressed by BMI 1. Another polycomb group protein is Mel 18. Increased expression of Melanoma nuclear protein 18 (a tumor suppressor protein) was found in cancer of medulla, melanoma, hodgin lymphoma [22-24]. Polycomb repressive complex 2 (PCR2), begins silencing via (H3K27) histone H3 Lisine-27 methylation, enclosing Ezh2, Suz12, Eed $[25,26]$. H3K27 methylation engage PRC1 binding to chromatin for stable gene silencing $[27,28]$. PCR2 also functions by interacting with long non coding RNA (HOTAIR) and aid enzymes of histone modification that bind DNA/RNA to engage polycombgroup proteins to its gene of specific target.

\section{Conclusion}

This review depicts the relationship between ageing and cancer and role of poly comb group proteins. In tissues at young age, the growth factors, inhibitory signals prevent tumor cell proliferation but during old age, accumulated senescence cells synthesize enzymes of disruptive nature, altered growth factors, cytokines that destroy tissue structure creating a conducive for cancer development. But, the exact mechanism linking these two factors has to be dealt a lot and require in depth research. It is obvious, that genes of poly comb group protein targets are more silenced through DNA methylation and also poly comb group proteins have dual role in senescence, gene silencing, ageing and cancer.

\section{Acknowledgement}

I would like to acknowledge Dr. C. Swaminathan, Dr. M. Manivannan, Dr. S. Parial and my teachers for their goodselves.

\section{References}

1. Shen J, Terry MB, Gurvich I, Liao Y, Senie RT, et al. (2007) Short telomere length and breast cancer risk: a study in sister sets. Cancer Res 67(11): 5538-5544.

2. Garber K (2012) At loose ends: telomere theories of aging and cancer begin to converge. J Natl Cancer Inst 104(11): 803-806.

3. Shammas MA (2011) Telomeres, lifestyle, cancer, and aging. Curr Opin Clin Nutr Metab Care 14(1): 28-34.

4. Campisi J (2013) Aging, cellular senescence, and cancer. Annu Rev Physiol 75: 685-705.

5. Balducci L, Ershler WB (2005) Cancer and ageing: a nexus at several levels. Nat Rev Cancer 5(8): 655-662.

6. Hoffe S, Balducci L (2012) Cancer and age: general considerations. Clin Geriatr Med 28(1): 1-18.

7. Bracken AP, Helin K (2009) Polycomb group proteins: Navigators of lineage pathways led astray in cancer. Nat Rev Cancer 9(11): 773-784.

8. Ringrose L, Paro R (2004) Epigenetic regulation of cellular memory by the Polycomb and Trithorax group proteins. Annu Rev Genet 38: 413-443.

9. Levine SS, King IF, Kingston RE (2004) Division of labor in polycomb group repression. Trends Biochem Sci 29(9): 478-485.

10. Ringrose L (2006) Polycomb, trithorax and the decision to differentiate. Bioessays 28(4): 330-334.

11. Groth A, Rocha W, Verreault A, Almouzni G (2007) Chromatin challenges during DNA replication and repair. Cell 128(4): 721-733.

12. Pasini D, Bracken AP, Jensen MR, Denchi EL, Helin K, et al. (2004) Suz12 is essential for mouse development and for EZH2 histone methyltransferase activity. EMBO J 23(20): 4061- 4071.

13. O'Carroll D, Erhardt S, Pagani M, Barton SC, Surani MA, et al. (2001) The polycomb-group gene Ezh2 is required for early mouse development. Mol Cell Biol 21(13): 4330-4336.

14. Faust C, Schumacher A, Holdener B, Magnuson T (1995) The eed mutation disrupts anterior mesoderm production in mice. Development 121(2): 273-285.

15. Teschendorff AE, Menon U, Gentry-Maharaj A, Ramus SJ, Weisenberger DJ, et al. (2010) Age-dependent DNA methylation of genes that are suppressed in stem cells is a hallmark of cancer. Genome Res 20(4): 440-446.

16. Chatoo W, Abdouh M, David J, Champagne MP, Ferreira J, et al. (2009) The polycomb group gene Bmi1 regulates antioxidant defenses in neurons by repressing p53 pro-oxidant activity. J Neurosci 29(2): 529-542.

17. He XT, Cao XF, Ji L, Zhu B, Lv J, et al. (2009) Association between Bmi-1 and clinicopathological status of esophageal squamous cell carcinoma. World J Gastroenterol 15(19): 2389-2394. 


\section{Current Trends in Biomedical Engineering \& Biosciences}

18. Nowak K, Kerl K, Fehr D, Kramps C, Gessner C, et al. (2006) BMI1 is a target gene of E2F-1 and is strongly expressed in primary neuroblastomas. Nucleic Acids Res 34(6): 1745-1754.

19. Shafaroudi AM, Mowla SJ, Ziaee SA, Bahrami AR, Atlasi Y, et al. (2008) Over expression of BMI1 a polycomb group repressor protein in bladder tumors: a preliminary report. Urol J 5(2): 99-105.

20. Mohty M, Yong AS, Szydlo RM, Apperley JF, Melo JV, et al. (2007) The polycomb group BMI1 gene is a molecular marker for predicting prognosis of chronic myeloid leukemia. Blood 110(1): 380-383.

21. Jacobs JJ, Kieboom K, Marino S, DePinho RA, van Lohuizen M, et al. (1999) The oncogene and Polycomb-group gene bmi-1 regulates cell proliferation and senescence through the ink $4 \mathrm{a}$ locus. Nature 397(6715): 164-168.

22. Dukers DF, Van Galen JC, Giroth C, Jansen P, Sewalt RG, et al. (2004) Unique polycomb gene expression pattern in Hodgkin's lymphoma and Hodgkin's lymphoma-derived cell lines. Am J Pathol 164(3): 873-881.

23. Tagawa M, Sakamoto T, Shigemoto K, Matsubara H, Tamura Y, et al. (1990) Expression of novel DNA-binding protein with zinc finger structure in various tumor cells. J Biol Chem 265(32): 20021-20026.
24. Wiederschain D, Chen L, Johnson B, Bettano K, Jackson D, et al. (2007) Contribution of polycomb homologues Bmi-1 and Mel-18 to medulloblastoma pathogenesis. Mol Cell Biol 27(13): 4968-4979.

25. Kirmizis A, Bartley SM, Kuzmichev A, Margueron R, Reinberg D, et al. (2004) Silencing of human polycomb target genes is associated with methylation of histone H3 Lys 27. Genes Dev 18(13): 1592-1605.

26. Lund AH, Van Lohuizen M (2004) Polycomb complexes and silencing mechanisms. Curr Opin Cell Biol 16(3): 239-246.

27. Czermin B, Melfi R, McCabe D, Seitz V, Imhof A, et al. (2002) Drosophila enhancer of Zeste/ESC complexes have a histone H3 methyltransferase activity that marks chromosomal Polycomb sites. Cell 111(2): 185196

28. Shao Z, Raible F, Mollaaghababa R, Guyon JR, Wu CT, et al. (1999) Stabilization of chromatin structure by PRC1, a Polycomb complex. Cell 98(1): 37-46

Your next submission with Juniper Publishers will reach you the below assets

- Quality Editorial service

- Swift Peer Review

- Reprints availability

- E-prints Service

- Manuscript Podcast for convenient understanding

- Global attainment for your research

- Manuscript accessibility in different formats

( Pdf, E-pub, Full Text, Audio)

- Unceasing customer service

Track the below URL for one-step submission

https://juniperpublishers.com/online-submission.php 